\title{
Pengaruh Media Kartu Kuartet Terhadap Kemampuan Membaca Siswa dalam Pelajaran Bahasa Indonesia
}

\author{
Hemas Maya Sulastri1*, Yopa Taufik Saleh², Sunanih ${ }^{3}$ \\ 123 Universitas Muhammadiyah Tasikmalaya
}

\begin{abstract}
Abstrak
Tujuan dari penelitian ini adalah untuk menguji pengaruh media kartu kuartet terhadap kemampuan membaca siswa dalam pembelajaran Bahasa Indonesia kelas 2 SD Negeri 2 Argasari. Penelitian ini menggunakan metode eksperimen dengan desain penelitian ini adalah Pre - Eksperimental dengan bentuk desain One - Group Pre test - Post test Design, Populasi penelitian sebanyak 19 responden dan sampel sebanyak 19 orang. Pengambilan sampel dengan quota sampling. Pengumpulan data melalui lembar wawancara dan test, pengolahan data kuantitatif diselesaikan melalui pengolahan data deskriptif dengan uji hipotesis. Hasil penelitian tentang kemampuan membaca siswa pada mata pelajaran bahasa Indonesia dengan menggunakan media kartu kuartet terdapat perbedaan dan peningkatan rata-rata kemampuan membaca siswa sebelum dan sesudah perlakuan. Dengan nilai signifikansi 0,003 $<0,05$ sehingga hipotesis diterima.
\end{abstract}

\section{Kata Kunci:}

Kemampuan membaca, kuartet kartu

\begin{abstract}
The purpose of this research is to test the influence of the card media Quartet on the ability to read students in Bahasa Indonesia study Grade 2 SDN 2 Argasari. This study used experimental methods with the design of this research was Preexperimental with the design form of One - Group Pre test - Post test Design, study population as much as 19 respondents and samples as many as 19 people. Sampling with quota sampling. Data collection through interview and test sheets, quantitative data processing is completed through descriptive data processing with hypothesized testing. The results of the study on the ability to read students in Bahasa Indonesia by using Media Card Quartet There are differences and the average increase in the ability to read students before and after treatment. With significance value $0.003<0.05$ so hypotheses are accepted.
\end{abstract}

\section{Keywords:}

Reading ability, card quartet

\footnotetext{
* Corresponding author. 


\section{PENDAHULUAN}

Pendidikan merupakan suatu proses yang mencakup tiga dimensi, individu, masyarakat atau komunitas nasional dari individu tersebut, dan seluruh kandungan realitas, baik material maupun spiritual yang memainkan peranan dalam menentukan sifat, nasib, bentuk manusia maupun masyarakat.

Pendidikan lebih dari sekedar pengajaran, yang dapat dikatakan sebagai suatu proses transfer ilmu, transformasi nilai, dan pembentukan kepribadian dengan segala aspek yang dicakupnya. Dengan demikian pengajaran lebih berorientasi pada pembentukan spesialis atau bidangbidang tertentu, oleh karena itu perhatian dan minatnya lebih bersifat teknis. Pendidikan merupakan suatu proses yang diperlukan untuk mendapatkan keseimbangan dan kesempurnaan dalam perkembangan individu maupun masyarakat. Penekanan pendidikan dibanding dengan pengajaran terletak pada pembentukan kesadaran dan kepribadian individu atau masyarakat di samping transfer ilmu dan keahlian. Dengan proses semacam ini suatu bangsa atau negara dapat mewariskan nilai-nilai keagamaan, kebudayaan, pemikiran dan keahlian kepada generasi berikutnya, sehingga mereka betul-betul siap menyongsong masa depan kehidupan bangsa dan negara yang lebih cerah (Nurkholis, 2013).

Kemajuan dan perkembangan pendidikan menjadi faktor keberhasilan suatu bangsa. Beberapa indikasi dapat dilihat dari kemajuan dunia barat seperti Amerika dan Eropa yang selalu menjadi anutan setiap berbicara masalah pendidikan. Hal ini diketahui dari berbagai data yang telah memberi- kan informasi tentang keungngulan dibidang pendidikan seperti model pembelajaran, hasil-hasil penelitian, produk-produk lulusan dan sebagainya. Bangsa Indonesia sebagai bangsa yang dalam posisinya masih dikatakan sebagai Negara berkembang sedang mencari bentuk tentang bagaimana cara dan upaya agar menjadi negar maju terutama dibidang pendidikan. Dan sistem pendidikan di Indonesia adalah mengacu pada Sistem Pendidikan Nasional yang merupakan sistem pendidikan yang akan membawa kemajuan dan perkembangan bangsa dan menjawab tantangan zaman yang selalu berubah hal ini sebagaimana visi dan misi Sistem Pendidikan Nasional yang tertuang dalam UU RI NO. 20 tahun 2003 tentang SISDIKNAS adalah sebagai berikut: "Terwujudnya sistem pendidikan sebagai pranata sosial yang kuat dan berwibawa untuk memberdayakan semua warga Negara Indonesia berkembang menjadi manusia yang berkualitas sehingga mampu dan proaktif menjawab tantangan zaman yang selalu berubah." Adapun misi yang diemban oleh SISDIKNAS adalah: "Mengupayakan perluasan dan pemerataan kesempatan memperoleh pendidikan yang bermutu bagi seluruh rakyat (UU RI SISDKNAS: 41)." (Munirah, 2015).

Keterampilan berbahasa tidak dapat diperoleh melalui kegiatan menghafal. Keterampilan berbahasa bukanlah sesuatu yang dapat diajarkan melalui uraian atau penjelasan semata. Mahasiswa tidak dapat memperoleh keterampilan berbahasa hanya dengan duduk dan mendengar keterangan atau penjelasan dari pendidik. Keterampilan berbahasa dapat diperoleh dengan melakukan kegiatan berbahasa secara terus menerus (Soulisa, 2018).

Kemapuan membaca merupakan kemampuan yang memegang peranan penting yang dapat dikuasai oleh seseorang, karena melalui kemampuan membaca dapat meningkatkan dan dapat memahami bacaan. Membaca juga hal sangat penting dalam kehidupan. Kemampuan membaca juga penting dalam pendidikan yaitu agar peserta didik mampu memahami isi bacaan dengan menangkap informasi secara tepat dan cepat. Sama halnya dengan pendapat Rahmi (2008: 1) bahwa kemampuan membaca sangat penting yang harus di miliki setiap orang. Dalam pendidikan dan pengajaran pembelajaran membaca mempunyai strategis dan usaha terus menerus.

Selain itu membaca merupakan bagian dari proses pendidikan mengembangkan potensi diri sehingga memiliki kemampuan berfikir jernih dalam prestasi akademik. Tetapi pada dasarnya membaca juga hal yang sangat membosankan bagi orang yang tidak gemar membaca dan tidak memiliki minat baca. Karena membaca bukan hanya sekedar membaca saja, perlu juga keterampilan untuk dapat menangkap penjelasan dari sesuatu yang di baca.

Selain penting, membaca juga bagian dari proses pendidikan. Seperti yang tercantum dalam permendikbud No. 67 Tahun 2013 tentang kerangka dasar dan stuktur kurikulum bahwa peserta didik di berikan kesempatan dalam mengembangkan potensi kemampuan berfikir rasional dalam kecerdasan akademik dengan pemberian makna terhadap sesuatu yang di lihat, didengar, dibaca, dan di pelajari dari warisan budaya berdasarkan makna yang di tentukan oleh lensa budayanya dan tingkatan pematangan pisik serta psikologis yang di sesuaikan dengan peserta didik.

Sekolah (pendidikan) merupakan sebagai salah satu tempat yang di percaya untuk melahirkan siswa yang mampu membaca dan memiliki pengetahuan. Rendahnya minat dan kemampuan membaca siswa akan memberi pengaruh pada kemampuan akademik siswa. Permasalahan rendahnya kemampuan membaca peserta didik yaitu kurang motivasi siswa untuk mempelajari buku-buku tertentu di luar buku paket, selain itu permasalahan dalam rendahnyan kemampuan membaca yaitu kebanyakan dari sistem pembelajaran yang di lakukan di sekolah masih bersifat Teacher center (pembelajaran berpusat pada 
guru), yaitu guru merupakan satu-satunyan sumber informasi di dalam pembelajaran sehingga siswa akan merasa jenuh jika pembelajaran bersifat Teacher center karena kemampuan yang di peroleh siswa dalam belajar juga dapat dipengaruhi dari penyampaian guru dalam menyampaikan maksud dari pembelajaran. hal ini sama dengan pendapat Nashar (2004: 77) yang menyatakan bahwa hasil belajar adalah kemampuan yang diperoleh siswa setelah melakukan kegiatan belajar. Selain itu penggunaan media pembelajaran Indonesia aspek membaca jarang sehingga membuat siswa merasa jenuh kalau di suruh membaca.

Berdasarkan wawancara dengan guru kelas 2 SD Negeri 2 Argasari yaitu Ibu Nunung Rostika, S.Pd. SD menyatakan bahwa kemampuan membaca di kelas tersebut masih rendah dan penggunaan media pembelajarannyapun hanya berpusat kepada guru, penggunaan media pembelajaran sebagai alat bantu/sumber belajar juga masih sangat terbatas. Hal ini menyebabkan kemampuan membaca yang masih rendah. Siswa masih mengalami kesulitan membaca saat tes membaca yang dilakukan guru. Sehingga banyak nilai peserta didik di bawah Kriteria Ketuntasan Minimal (KKM). Sebagaimana diketahui bahwa KKM mata pelajaran bahasa Indonesia adalah 70 . Ada kemungkinan rendahnya nilai kompetisi peserta didik disebabkan oleh strategi penyampaian pembelajaran yang kurang tepat yaitu miskinnya penggunaan media pembelajaran. Sedangkan guru memegang peran penting untuk menciptakan suatu pembelajaran yang menarik bagi peserta didik. Oleh karena itu guru harus dapat memaksimalkan panca indra peserta didik dalam menyerap materi pelajaran, salah satunya dengan menggunakan media pembelajaran kartu kuartet.

Sukamelang dalam Medisty (2013: 2) menjelaskan bahwa kartu kuartet adalah sejenis permainan yang terdiri atas beberapa jumlah kartu bergambar yang dari kartu bergambar tersebut tertera keterangan berupa tulisan yang menerangkan gambar tersebut.

Dengan menggunakan media kartu kuartet selain mempertinggi kemampuan membaca juga diharapkan dapat membantu peserta didik mengingat materi pelajaran dengan baik. Pemilihan media kartu kuartet ini didasari pertimbangan bahwa media visual berupa gambar lebih mudah diakses siswa, dan penggunaanyapun tidak bergantung pada tenaga listrik. Selain itu, kelebihan media kartu kuartet adalah tidak membutuhkan alat pendukung penyajian yang lain. Kartu kuartet sebagai media juga memiliki kekhususan dan keunikan, sehingga sesuai dengan gaya belajar siswa Sekolah Dasar yang masih dalam usia anak-anak, yaitu belajar selayaknya bermain. Dengan demikian anak-anak dapat memainkannya di segala tempat dan di setiap waktu dengan permainan yang menarik namun memuat materi pembelajaran.

Selain media kartu kuartet ini sebagai media yang menarik karena sesuai dengan gaya peserta didik yang masih senang bermain juga di harapkan peserta didik dalam aspek membacanya lancar dan peserta didik dapat lebih mengingat materi yang di ajarkan. Hal ini sama dengan pendapat Gunadi (2014: 1) tentang manfaat anak bermain, bentuk kartu kuartet yang sudah di modifikasi untuk pembelajaran bahasa Indonesia maka dapat dirumuskan beberapa tujuan dari penggunaan media kartu kuartet ini yaitu

1. Dapat mempermudah siswa dalam mengingat pembelajaran, karena kebanyakan siswa setelah belajar di sekolah baru perapa langkah saja keluar kelas sudah lupa dengan apa yang di pelajari tadi. Dengan media kartu kuartet siswa dapat mengingat kata-kata yang memuat di dalam kartu tersebut karena di lengkapi dengan gambar.

2. Media kartu kuartet ini dapat melatih kemampuan kognitif siswa. karena permainannya membutuhkan strategi yang dapat mengalahkan lawan bermainnya. Sehingga dapat memperkaya kemampuan berpikir siswa.

3. Dengan penggunaan media kartu kuartet akan membuat siswa yang tadinya malu-malu dan canggung dalam berbicara bahasa Indonesia pada akhirnya dapat berani berbicara bahasa Indonesia.

4. Permainan kartu kuartet ini juga dapat membangkitkan siswa untuk berfikir tepat dan cermat.

5. Dengan permainan kartu kuartet juga dapat meringankan kejenuhan dalam belajar di kelas khususnya dalam pembelajaran bahasa Indonesia.

6. Media kartu kuartet ini juga dapat membuat suasana belajar bahasa Indonesia lebih menarik dan menyenangkan. Karena bisa bermain sambil belajar.

Jadi alasan-alasan inilah yang mendasari penelitian dilakukan. Maka, penulis dalam penelitian ini mengangkat judul "Pengaruh Media Kartu Kuartet terhadap Kemampuan Membaca Siswa dalam Pembelajaran Bahasa Indonesia kelas 2 SD Negeri 2 Argasari”. 


\section{METODE PENELITIAN}

Dalam penelitian terdapat beberapa pendekatan dan jenis penelitian. adapun pendekatan penelitian yang dilakukan dalam penelitian ini adalah pendekatan kuantitatif. Menurut Iskandar (2013: 20):

Penelitian kuantitatif adalah penelitian yang dilakukan untuk mendapatkan jawaban dari permasalahan atau gambaran umum tentang suatu fenomena atau gejala yang dilandasi pada teori, asumsi atau andaian, dalam hal ini dapat diartikan sebagai pola pikir yang menunjukkan hubungan antara variabel - variabel yang akan diteliti, sekaligus mencerminkan jenis dan jumlah rumusan masalah yang perlu dijawab melalui penelitian, teori yang digunakan adalah untuk merumuskan hipotesis, dan teknik analisis statistik yang hendak digunakan.

Jenis atau metode yang digunakan dalam penelitian ini adalah metode eksperimen. Gay (1998) dalam Sudaryono (2019: 90), "metode eksperimen dapat mewakili pendekatan yang paling sahih dalam memecahkan masalah, baik secara praktis maupun teori.

Suharsimi (2010: 9) dalam Sudaryono (2019: 90) "memberikan penjelasan tentang penelitian eksperimen dimana peneliti dengaja membangkitkan timbulnya suatu kejadian atau keadaan, kemudian diteliti bagaimana akibatnya. Dengan kata lain eksperimen adalah suatu cara untuk memberi hubungan sebab akibat (hubungan kasual) antara dua faktor yang sengaja di timbulkan oleh peneliti dengan mengeliminasi atau mengurangi atau menyisihkan faktor-faktor lain yang mengganggu.

Bentuk desain dalam penelitian ini adalah Pre-Eksperimental Design dengan macam bentuk desain One - Group Pre test - Post test Design, dengan alasan hasil perlakuan lebih akurat, karena dapat membandingkan hasil sebelum perlakuan dan setelah perlakuan. Bentuk desain One-Group Pre Test - Post Test Design yaitu terdapat suatu kelompok yang diberikan Pre Test sebelum perlakuan kemudian diberikan perlakuan dan diberi Post Test setelah perlakuan. Desain penelitian ini dapat digambarkan sebagai berikut:

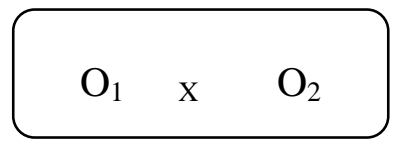

Gambar 2. One-Group Pre Test - Post Test Design

Populasi merupakan keseluruhan objek yang menjadi sasaran penelitian. Dengan demikian, yang menjadi populasi dalam penelitian ini adalah seluruh siswa kelas 2 SD Negeri 2 Argasari sebanyak 19 orang. Sampel adalah "bagian dari jumlah dan karakteristik yang dimiliki oleh populasi. Bila populasi besar, dan peneliti tidak mungkin mempelajari semua yang ada pada populasi, misalnya karena keterbatasan dana, tenaga dan waktu, maka peneliti dapat menggunakan sampel yang diambil dari populasi itu. Adapun sampel yang diambil dalam penelitian ini sebanyak 1 kelas yang berjumlah 19 orang.

Dalam sampel ini menggunakan sampling jenuh. Sampling jenuh adalah teknik penentuan sampel bila semua anggota populasi digunakan sebagai sampel.

Penelitian ini direncanakan akan dilaksanakan di SD Negeri 2 Argasari Tasikmalaya yang beralamat di Kp.Sangiangteras Kota Tasikmalaya. Penelitian ini akan dilakukan bulan bulan Desember Sampai bulan April 2020.

Penelitian ini dilakukan pada pembelajaran semester 2 tahun ajaran 2019/2020 mata pelajaran Bahasa Indonesia Tema Merawat Hewan dan Tumbuhan. Jenis data yaitu data Kuantitatif berupa data kemampuan membaca pada materi hewan dan tumbuhan yang diperoleh dari nilai pretes, postes, selanjutnya dianalisis secara statistik deskriptif dan statistic dengan uji t.

\section{ANALISIS DAN PEMBAHASAN}

Media Kartu Kuartet dilaksanakan dalam pembelajaran bahasa Indonesia aspek kemampuan membaca pada siswa kelas 2 SD Negeri 2 Argasari, berdasarkan hasil pre test dan post tes, menunjukkan bahwa terdapat peningkatan Untuk lebih jelasnya, model visual kategori pre test dapat dilihat dalam diagram lingkaran berikut : 


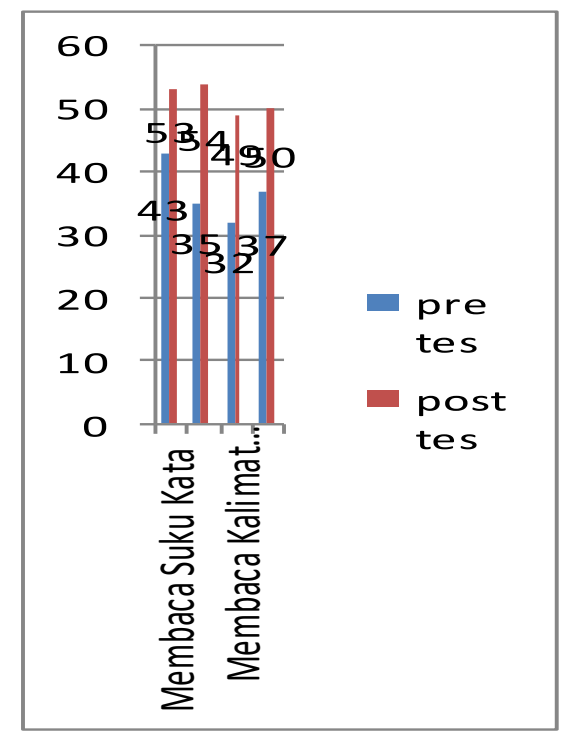

Gambar 1. Diagram rata-rata pre test dan Post tes Siswa

Pada gambar 1. dapat dilihat bahwa dengan menggunakan media kartu kuartet terjadi peningkatan kemampuan membaca siswa kelas 2 yang signifikan. Dari rata-rata secara keseluruhan terjadi peningkatan dalam setiap aspek yang dijadikan dasar pengukuran aspek kemampuan membaca siswa.

Keberadaan suatu media dalam pembelajaran akan sangat membantu dalam kegiatan belajar mengajar di kelas dan dapat mempermudah penyampaian materi secara efektif karena akan ada interaksi positif antara guru, proses pembelajaran dan siswa sebagaimana pendapat Sudjana (2015 : 95) menjelaskan bahwa "Kegiatan pembelajaran terjadi melalui interaksi peserta didik di satu pihak dan pendidik di pihak lainya".

Setelah dilakukan pre test untuk mengetahui kemampuan membaca siswa selama ini kemudian diberikan perlakuan (treatment) media kartu kuartet dalam pembelajaran di kelas 2 SD Negeri 2 Argasari. Melalui media pembelajaran, siswa dapat membangun suasana belajar yang dinamis, penuh semangat dan antusiasme serta menciptakan suasana membaca yang menyenangkan (fun).

Media kartu kuartet dalam pembelajaran juga dapat membantu siswa memahami suatu konsep atau materi hal ini senada dengan pendapat Suryatna (2005:12) yang menyatakan bahwa : "Pembelajaran dengan menggunakan media akan sangat efektif untuk menjelaskan suatu pengertian niskala (abstrak) dan konsep yang sulit dijelaskan dengan kata-kata". Dengan media kartu kuartet siswa dapat meningkatkan kemampuan membaca.

Berdasarkan hasil analisis maka diketahui terdapat peningkatan dari hasil tersebut, dapat diartikan siswa dapat lebih meingkatkan kemampuan membaca dari pengetahuan awalnya selama ini dengan media kartu kuartet.

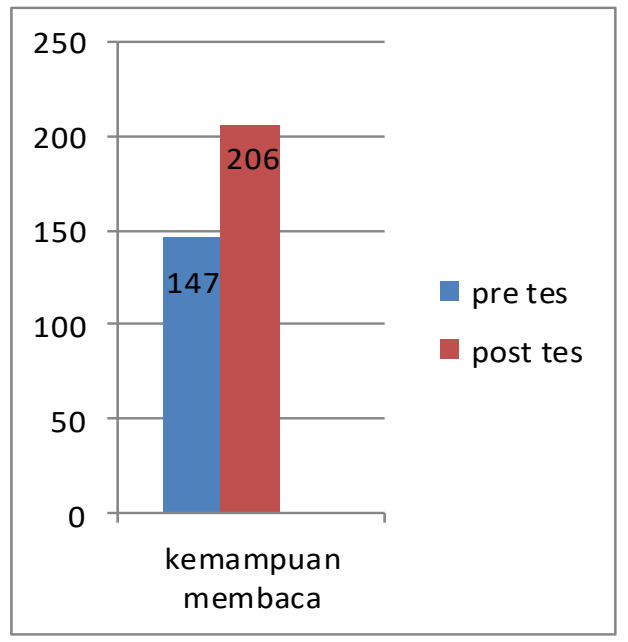

Gambar 2. Diagram rata-rata kemampuan membaca 
Pada gambar 2. dapat dilihat bahwa dengan menggunakan media kartu kuartet terjadi peningkatan kemampuan membaca siswa kelas 2 yang signifikan. Dimana terdapat peningkatan hasil secara keseluruhan dari 147 point menjadi 206 point. Sehingga terdapat perbedaan kemampuan membaca siswa kelas 2 SD Negeri 2 Argasari. antara sebelum dan sesudah menggunakan media kartu kuartet.

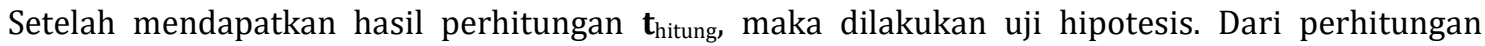
diatas dapat diketahui bahwa $\mathbf{t}_{\text {hitung }}$ adalah 3.463 dan $\mathbf{t}_{\text {tabel }}$ dengan $\mathrm{df}(\mathrm{N}-1)=18$ untuk $5 \%$ adalah 2,110, dapat diketahui bahwa $\mathbf{t}_{\text {hitung }} \geq \mathbf{t}_{\text {tabel }}$ dengan nilai $3.463 \geq 2,110$ untuk $5 \%$. Hasil tersebut membuktikan $\mathrm{H}_{1}$ yang menyatakan bahwa media kartu kuartet dapat meningkatkan kemampuan membaca siswa diterima.

Kartu kuartet memiliki kelebihan sebagai media, metode, sekaligus permainan berupa kartu baca yang berisi tulisan yang bermanfaat untuk membantu meningkatkan membaca dan penguasaan kosa kata dengan cepat bagi anak. Pemilihan kata-kata pada kartu kuartet dalam pembelajaran tentu harus disesuaikan dengan tujuan pembelajaran. Kata-kata tersebut hendaknya menampilkan gagasan, informasi, konsep-konsep yang mendukung tujuan, serta kebutuhan pengajaran serta juga harus memperhatikan partumbuhan dan perkembangan siswa. Media kartu kuartet tergolong dalam media berbasis visual yang memegang peranan penting dalam proses belajar.

Dari hasil penelitian yang dilakukan peneliti terhadap responden, dapat dijelaskan bahwa penerapan pembelajaran dengan menggunakan media kartu kuartet sangat tepat untuk membantu kemampuan membaca. Hal ini dilakukan sesuai dengan tujuan dan tema yang ditetapkan oleh pengajar.

Berdasarkan pada pengalaman langsung peneliti dalam proses penelitian ini, ada beberapa keterbatasan yang dialami dan dapat menjadi beberapa faktor yang agar dapat untuk lebih diperhatikan bagi peneliti-peneliti yang akan datang dalam lebih menyempurnakan penelitiannya karna penelitian ini sendiri tentu memiliki kekurangan yang perlu terus diperbaiki dalam penelitian-penelitian kedepannya. Beberapa keterbatasan dalam penelitian tersebut, antara lain :

a. Jumlah responden yang hanya 19 orang, tentunya perlu perencanaan yang matang, sebab semakin sedikit jumlah responden maka tingkat keberhasilan diharapkan lebih baik.

b. Objek penelitian hanya di fokuskan pada media kartu kuartet dan kemampuan membaca sehingga waktu pelaksanaan pembelajaran kurang sesuai target.

Berdasarkan pembahasan diatas, dapat diketahui bahwa tujuan utama dalam mengembangkan perangkat media pembelajaran menggunakan kartu kuartet yang memenuhi kritetia, praktis dan efektif dengan menggunakan model pengembangan perangkat pembelajaran telah terpenuhi, sehingga perangkat ini dapat dijadikan sebagai perangkat atau prototype final yang layak untuk disebarkan ke sekolah lain. Proses pengembangan perangkat pembelajaran dalam penelitian ini menggunakan model pengembangan perangkat 4D, dilaksanakan mulai proses pendefinisian, proses perancangan, kemudian hasil rancangan tersebut divalidasi untuk menghasilkan perangkat pembelajaran yang dapat diuji cobakan pada salah satu sekolah (proses pengembangan), hingga mendapatkan hasil yang mendukung kualitas perangkat pembelajaran layak untuk disebarkan (proses penyebaran).

Pada penelitian ini perangkat yang dikembangkan merupakan perangkat media pembelajaran dengan menggunakan pendekatan permainan kartu pada aspek membaca dengan tujuan akhir perangkat pembelajaran ini memberikan perubahan yang positif terhadap pelaksanaan pembelajaran, hal ini dapat dilihat terhadap kepraktisan dan keefektifan perangkat pembelajaran saat tahap pengembangan dilaksanakan. Dari proses dan hasil belajar selama pembelajaran dengan pendekatan permainan kartu kuartet serta data-data pengamatan observer selama uji coba di atas ditemukan beberapa hal antara lain;

a. Dengan pembelajaran menggunakan pendekatan permainan kartu kuartet membantu peserta didik belajar untuk mengkonstruksi pemikiran dan pengetahuannya sendiri.

b. Dalam proses pembelajarannya peserta didik termotivasi oleh teman sekolompoknya untuk bisa berkomunikasi.

c. Kepercayaan diri peserta didik lebih terbangun lagi saat presentasi. Dengan demikian, hasil pengembangan perangkat media pembelajaran menggunakan permainan kartu kuartet telah memenuhi kriteria kevalidan, kepraktisan dan keefektifan sehingga perangkat yang telah diuji cobakan dalam pembelajaran sudah bisa dijadikan prototipe final dan layak digunakan.

Media pembelajaran kartu kuartet pada pelajaran bahasa Indonesia aspek membaca layak dipertimbangkan sebagai salah satu media yang dapat digunakan dalam proses pembelajaran di kelas. .Guru diharapkan mengetahui proses pembuatan dan pengembangan media pembelajaran, sehingga dapat membuat media yang sesuai dengan kebutuhan peserta didik. Penelitian relevan selanjutnya agar dapat melakukan pengembangan media pembelajaran kartu kwartet pada pokok bahasan yang berbeda sehingga menambah variasi materi dalam media pembelajaran kartu kuartet. 


\section{KESIMPULAN}

Berdasarkan hasil penelitian tentang kemampuan membaca siswa pada mata pelajaran bahasa Indonesia dengan menggunakan media kartu kuartet maka peneliti menyimpulkan media kartu kuartet efektif dan berpengaruh terhadap kemampuan membaca siswa dalam pembelajaran bahasa Indonesia kelas 2 SDN Negeri 2 Argasari. Kesimpulan tersebut dapat diketahui dari nilai rata-rata siswa sebelum dan sesudah diperlakukan dengan media kartu kuartet. Sebelum perlakuan menggunakan media kartu kuartet diperoleh nilai kemampuan sebesar 147 dengan klasifikasi rendah sedangkan setelah perlakuan menggunakan media kartu kuartet menjadi 206 dengan klasifikasi baik hal tersebut menunjukan adanya kenaikan rata-rata sebesar 59 poin. Hal ini juga dibuktikan pada uji signifikansi terlihat nilai sig.0,003 < 0,05 maka Ha diterima dan Ho ditolak. Penerimaan Ha menunjukan bahwa hasil tes akhir lebih baik dari tes awal.

Berdasarkan simpulan hasil penelitian peneliti memberikan saran sebagai berikut :

1. Bagi guru mata pelajaran Bahasa Indonesia dapat menjadikan referensi baru dalam pembelajaran membaca dengan menggunakan kartu kuartet.

2. Bagi guru dan siswa dapat menjadikan media kartu kuartet sebagai strategi baru dalam pembelajaran membaca.

Menjadi rujukan bagi peneliti selanjutnya dalam berkarya ilmiah. Penelitian yang dilakukan oleh peneliti dapat digunakan sebagai tinjauan pustaka untuk mengembangkan kajian lain dengan berbagai model ataupun teknik pengajaran yang berbeda dan meneliti keefektifan penggunaan teknik pengajaran ini pada keterampilan lainnya.

\section{DAFTAR PUSTAKA}

Arsyad, Azhar. 2013. Media Pembelajaran. Jakarta: Raja Grafindo Persada.

Abdurrahman, Mulyono. 2013. Pendidikan Bagi Anak Berkesulitan Brlajar. Jakarta: Rineka Cipta.

Arikunto, Suharsimi. 2013. Prosedur Penelitian. Jakarta: Rineka Cipta.

Arikunto, Suharsimi. 2016. Dasar-dasar Evaluasi Pendidikan. Jakarta: Bumi Aksara.

Sudaryono. 2019. Metodologi Oenelitian Kuantitatif, Kualitatif, Mix Method. Depok: Raja Grafindo Persada.

Kurniawan, Asep. 2018. Metodologi Penelitian Pendidikan. Bandung: Remaja Posdakarya.

Munirah. 2015. Sistem Pendidikan Di Indonesia: Antara Keinginan Dan Realita . Jurnal Auladuna, Vol. 2 No. 2 Desember 2015.

Nurkholis. 2013. Pendidikan Dalam Upaya Memajukan Teknologi . Jurnal Kependidikan, Vol. 1 No. 1 Nopember 2013

Subhani. 2011. Kartu Kuartet dan Pembelajaran (Online). Tersedia : http://stkipselong.blogspot.com/2011/01/kartu-kuartet-dan-pembelajaran.htm1. (13 November 2019).

Soulisa, Irwan . 2018. Penggunaan Bahasa Indonesia Lisan Baik Dan Benar Dalam Kelompok Kecil Kalangan Mahasiswa Prodi Bahasa Dan Sastra Indonesia Universitas Victory Sorong . Jurnal Kredo Vol. 2 No. 1 Oktober 2018.

Tarigan, Henry. 2015. Membaca sebagai Suatu Keterampilan Berbahasa. Bandung: Angkasa.

Tampubolon. 2008. Mengembangkan Minat dan Kebiasaan Membaca pada Anak. Bandung: Alfabeta. 